\title{
O RETRATO DE DORIAN GRAY
}

\section{Carlos Cassiano Dalto ${ }^{1}$}

Universidade Estadual de Londrina, Londrina, Brasil

Oscar Wilde nasceu na Inglaterra, em 1854. O seu pai era médico e a sua mãe jornalista e poetisa. Publicou seus primeiros poemas em 1878, na cidade de Londres e ganhou o prêmio Newdigate, com destaque por sua escrita irônica e discurso preconceituoso sobre a sociedade vitoriana.

Ao longo de sua vida viveu em várias cidades dos Estados Unidos e da Europa, trabalhou como redator-chefe da revista Woman`s Word, tendo publicado diversos livros, como por exemplo "Poemas”, e peças teatrais, como “A Burguesa de Padrua”. Em 1890, lançou a primeira versão de "O Retrato de Dorian Gray". O livro proporcionou-lhe notoriedade pela repercussão, pois chocou a sociedade inglesa da época, retratando a imoralidade dos principais personagens. Em 1900, aos 46 anos, Oscar Wilde morre de meningite cerebral após uma viagem a Roma e Nápoles, deixando dois filhos.

O Retrato de Dorian Gray tornou-se um verdadeiro clássico. A história se passa nos anos de 1800 e retrata personagens da alta classe burguesa, banhados a muito ouro, caracterizando-os com seus defeitos e qualidades. Dorian Gray é o principal personagem da obra. Tudo começa quando o artista plástico e pintor Basil Hallward, conhece Dorian em um evento da alta classe burguesa, fica encantado com a sua beleza e elegância e assim, propõe a ele fazer o seu retrato.

Com a amizade de Basil, Dorian conhece Lord Henry Wotton, que o convida para saírem e conhecerem a bela noite da cidade. Dorian começa a desfrutar o mundo da beleza e da satisfação sensual, até então, desconhecido por ele. Lord, com sua arrogância, passa a corromper Dorian Gray, “[...] sinto lhe informar, mas as mulheres apreciam a crueldade Dorian [...]” (WILDE, 2012, p.70). Assim, acredita Dorian que a única coisa boa da vida é o esteticismo e a duplicidade moral.

\footnotetext{
${ }^{1}$ Graduando em Geografia pela Universidade Estadual de Londrina (UEL). Bolsista do PET - Programa de Educação Tutorial em geografia, E-mail: carlos.cassiano1@uel.br
} 
Ao observar a sua beleza e elegância estampada naquele retrato e diante dos elogios de pessoas da alta sociedade, Dorian Gray resolve vender a sua alma para o retrato, temendo à velhice.

Certo dia, Dorian Gray nota algumas marcas estranhas na face de seu retrato. $\mathrm{Na}$ mesma noite, Lord convida Dorian para sair com garotas de programa. Dorian aceita. Quando retorna à sua casa, percebe que a imagem do retrato mudou novamente. E então, retira o retrato da parede da sala e esconde-o para ninguém perceber o fato. No dia seguinte, Dorian voltou a observar seu retrato e entendeu que a sua imagem estava envelhecendo, mas ele não.

Com essa descoberta, Dorian passa a ter uma vida de liberdade, várias experiências amorosas, sexuais, bebidas e drogas, “[...] decide estudar sobre os perfumes, aromas, música e arte da joalheria, para desenvolver uma verdadeira psicologia e paixão por mulheres. [...]" (WILDE, 2012, p. 85).

Enquanto Dorian aproveitava-se de tamanha liberdade, o seu retrato envelhece e registra as coisas maléficas que ocorrem com a sua alma. Inclusive a morte de Basil Hallward, um assassinato cometido por Dorian Gray, num momento de raiva. A princípio por saber que haviam tido um romance com uma mesma mulher, mas, principalmente, por ter sido questionado por Basil sobre a sua vida de sensualismo.

Depois de um tempo Dorian Gray foi observar o seu retrato novamente e percebeu as transformações. Passou a sentir-se incomodado, pois a sua consciência o fez enfrentar todas as culpas e responsabilidades. Ao lado do seu retrato, se deparou com a faca que usara para assassinar Basil Hallward, num gesto de fúria, na tentativa de livrar-se de seu passado e da alma que o perturbava, ele apunha o objeto sobre o retrato, mas o que não imaginava era que, ao matar o seu retrato, estava matando-se.“[...]Ao escutar um barulho, e seus gritos de agonia, os empregados da casa acordaram assustados e saíram correndo de seus quartos [...]"(WILDE, 2012, p.138). Ao ver Dorian Gray caído no chão, morto, perceberam retrato com sua aparência repulsiva, com a pele enrugada e degenerada. Foi impossível reconhece -lo. Seus anéis eram a única prova de que ali estava Dorian Gray.

Percebe-se que o autor propõe uma técnica de leitura bastante elucidativa, com uma referência ao século XIX. Sua eficiência e objetividade oferece detalhes em cada 
capítulo para aqueles que necessitam dominar a leitura. A obra oferece um universo encantador pela capacidade de relatar as aparências da alta sociedade burguesa, com suas ambiguidades, cujas artimanhas são capazes de enganar uns aos outros, porém não a si mesmas.

O texto é adaptado e ilustrado para uma leitura simples, objetiva e clara. Possui um glossário com conceitos da beleza da arte, utilizados naquela época. De modo geral, o domínio desta leitura pode ser praticado por estudantes do ensino médio, universitários e amantes de romances, em que é tratado, constantemente, o bem e o mal de uma sociedade que sempre se diz superior a outra.

\section{REFERÊNCIAS}

PRAZER DA LEITURA. Disponível em: https://www.leitoraviciada.com/2012/04/oprazer-da-leitura-da-abril-colecoes-o.html Acesso em: 14 abr.2020

WILDE, Oscar. O Retrato de Dorian Gray. Adaptado e Ilustrado: abril Coleções, 2012. $138 \mathrm{p}$.

Recebido em 14/04/2020.

Aceito em 31/07/2020.

Publicado em 07/11/2020. 